Sulphonamides and Penicillin in the

TREATMENT OF TRACHOMA

\title{
SULPHONAMIDES AND PENICILLIN IN THE TREATMENT OF TRACHOMA*
}

BY

\author{
F. S. LAVERY
}

DUBLIN

THERE has been considerable controversy as to whether or not sulphonamides have a specific effect on the virus of trachoma. The answer to the question has importance not only for the correct treatment of the disease, but it also has importance as an aid in the classification of the group of morphologically indistinguishable viruses to which that of trachoma belongs. The extensive literature on the subject has been reviewed so often that it would only be tedious if I were to do so again in this communication. Sufficient be it for me to say that of the numbers who have written on the subject a substantial majority has claimed a specific effect for sulphonamides upon the virus. Most of the protagonists of sulphonamides have depended upon clinical observation. This in a disease whose end-point is so ill-defined, and in which the stage at which it ceases to be infectious is largely a matter of conjecture. Some have submitted sulphonamides to the more critical test of examining smears of conjunctival scrapings for the presence or absence of the specific inclusion bodies before and after the course of treatment. The sulphonamide most extensively used has been sulphanilamide administered internally.

Thygeson ${ }^{1}$ claims that in cases in which specific inclusion bodies were found previous to the internal administration of sulphanilamide they could not be found afterwards. In this series of 31 cases of trachoma he found inclusion bodies in 16 ( 51.5 per cent.) before the commencement of sulphanilamide therapy. This is a high percentage of positives and is still the more remarkable in so much as 8 of the 16 cases are listed as being in either stage 3 or stage 2-3. The percentage of positives in the series of 54 cases of trachoma hereafter to be reported on was $33 \cdot 3$, and 53 per cent. of these were stage 1 . Julianelle ${ }^{2}$ in a series of 602 cases found that 32.7 per cent showed the presence of specific cell inclusions, and in an analysis by him of forty-two reports from various countries in which a grand total of 5,777 patients was recorded the percentage of positives was 30.8 . Thygeson reports that in all the 16 cases which were positive cell inclusions could not be found after so short a period as three days' treatment with sulphanilamide. In spite of this finding only 10 per cent. of the 16 cases are recorded as being " healed." He found that sulphanilamide therapy had no effect on secondary infection,

- Received for publication, July 26, 1946. 
and that in three cases of acute trachoma with discharge the conjunctival flora was normal, both before and after the treatment. In a subsequent series ${ }^{3}$ of 70 cases of trachoma (this series includes the above-mentioned 31 cases) he again reports favourably on the specific effect of sulphanilamide therapy; but he does not state the number of cases in which the cell inclusions were found before the commencement of treatment. MacCallan ${ }^{4}$ reports that after treating cases of trachoma with sulphapyridine he was able to identify specific cell inclusions.

There have been very few claims that penicillin has a specific effect on the virus of trachoma. Sorsby ${ }^{5}$ reports on the treatment of three cases with penicillin. In one of these inclusion bodies were present in epithelial scrapings before the commencement of treatment. The case is of little use for the evaluation of the therapeutic efficacy of penicillin as treatment was commenced by an expression. The penicillin was used in a concentration of 2,500 units per c.c. painted on the tarsal conjunctiva once per day. He does not state whether or not a search was made for inclusion bodies at the conclusion of treatment. He reports clinical cure of the case.

To date there appears to be general agreement that penicillin is only likely to be effective if administered locally.

The type of trachoma met with in and around Dublin is usually a less vigorous disease than that with which I was accustomed to deal when I first commenced to specialise in ophthalmology in 1927. One rarely comes across a fresh case which is complicated by sufficient pannus formation to interfere materially with vision. The disease most often manifests itself by the presence of follicles on the conjunctiva of the upper fornix and along the upper edge of the superior tarsal plate. Were it not for the finding of typical inclusion bodies the diagnosis in many cases would be doubtful. It is striking that on more than one occasion when they have not been found in the conjunctival scrapings taken from an obviously infected member of a family they have been found in the scrapings from a clinically less obviously infected brother or sister.

Most of this series of 54 cases of trachoma have already been reported on $\left(^{6}\right)$ from the point of view of the aetiology of trachoma in Ireland. They are now to be analysed in so far as the result of treatment of some of them with sulphonamides and penicillin might be of aid in the evaluation of the therapeutic effects of these drugs. The sulphonamide therapy employed was : internally the patients were given gr. $1 / 3$ per $\mathrm{lb}$. body weight of sulphanilamide in the 24 hours, accompanied by sufficient sod. bicarb. to combat nausea. The drug was divided into three equal daily 
doses. This was given for two weeks, and then half this quantity for a further week. Locally, during the full three weeks' period sol. sod. sulphacetamide 10 per cent. was instilled into the conjunctival sacs every three hours during the day, and last thing at night ung. sulphacetamide 6 per cent. was inserted into the conjunctival sacs.

In the cases selected for penicillin therapy the drug was administered locally in the form- of drops, 2,500 units per c.c. The drops were instilled into the conjunctival sacs every two hours during the 24 hours for a period of two weeks, and in addition, in cases Nos. 11 and 12 swabs soaked in the solution were inserted into the upper fornices for five minutes once per day.

In 18 of the 54 cases specific inclusion bodies were found. A number of the series were treated with sulphonamides and a lesser number with penicillin. Only cases in which inclusion bodies were found, either before or after treatment, are dealt with in this communication. It is appreciated that the inclusion of cases which were negative before treatment but were positive after treatment, while representing a true finding, is a weighing factor against the therapeutic value of sulphonamides or penicillin being established. It is felt that this weighing factor is more than counterbalanced by the difficulty in finding inclusion bodies in. conjunctival scrapings. While the identification of specific cell inclusions can be accepted as a positive result, failure to find them even after a long search is very far from proving the reverse.

Data concerning the cases treated with sulphonamides is set out in Table I, and that concerning the cases treated with penicillin in Table II.

TABLE I

\begin{tabular}{c|c|c|c|c|c}
\hline & & & & \multicolumn{2}{|c}{ Inclusion Bodies } \\
\cline { 4 - 5 } Case No. & Sex & Age & $\begin{array}{c}\text { Stage of } \\
\text { Disease }\end{array}$ & $\begin{array}{c}\text { Before } \\
\text { Treatment }\end{array}$ & $\begin{array}{c}\text { After } \\
\text { Treatment }\end{array}$ \\
\hline 1 & $\mathrm{~F}$ & 11 & Two & Present & Present \\
\hline 2 & $\mathrm{~F}$ & 14 & One & Present & Present \\
3 & $\mathrm{~F}$ & 22 & Two & Present & Absent \\
4 & $\mathrm{~F}$ & 9 & One & Present & Absent \\
5 & $\mathrm{M}$ & 34 & Two & Present & Absent \\
6 & $\mathrm{~F}$ & 8 & Two & Absent & Present \\
7 & $\mathrm{~F}$ & 10 & One & Present & $\begin{array}{c}\text { Absent } \\
\text { Pbsent }\end{array}$ \\
8 & $\mathrm{M}$ & 11 & One & Present & Absent \\
\hline
\end{tabular}

Data on cases treated with sulphonamide internally and sod. sulphacetamide locally. 
TABLE II

\begin{tabular}{|c|c|c|c|c|c|}
\hline \multirow[b]{2}{*}{ Case No. } & \multirow[b]{2}{*}{ Sex } & \multirow[b]{2}{*}{ Age } & \multirow[b]{2}{*}{$\begin{array}{l}\text { Stage of } \\
\text { Disease }\end{array}$} & \multicolumn{2}{|c|}{ Inclusion Bodies } \\
\hline & & & & $\begin{array}{c}\text { Before } \\
\text { Treatment }\end{array}$ & $\begin{array}{c}\text { After } \\
\text { Treatmen }\end{array}$ \\
\hline 1 & $\mathrm{~F}$ & 11 & Two & Present & Present \\
\hline 9 & $\mathrm{~F}$ & 16 & One & Present & Absent \\
\hline 10 & $\mathbf{M}$ & 15 & Twe & Present & Present \\
\hline 11 & $\mathrm{~F}$ & 12 & Two & Absent & Present \\
\hline 12 & $\mathrm{~F}$ & 8 & Two & Absent & Present \\
\hline
\end{tabular}

Data on cases treated with penicillin locally.

Case No. 1 is of interest as it is the only one reported on which was treated with both penicillin and sulphonamides. Inclusion bodies were found before the commencement of any treatment in February, 1945. After two weeks' treatment with penicillin they were again found. In December of the same year conjunctival scrapings were still positive; and they remained positive after sulphonamide therapy.

In Case No. 10 penicillin drops were instilled only into the right conjunctival sac, the left being kept as a control. After the conclusion of the course both eyes yielded positive results. When examined recently, after a lapse of ten months, the right eye presented the clinical appearance of a cure, while the disease is active in the left. The patient was on spasmodic classical trachoma treatment in the interval.

While the number of cases submitted is too small to draw definite conclusions from, it is of importance that in three cases inclusion bodies were identified after carefully controlled sulphonamide therapy. On the other hand, the five negative results in eight cases after the conclusion of sulphonamide therapy against the one negative result out of five cases treated with penicillin, could hardly be fortuitous.

I have to express my thanks to the Medical Research Council of Ireland for a grant-in-aid, and to Dr. P. N. Meenan for carrying out the pathological work connected with this communication.

\section{REFERENCES}

1. Thygeson, P.-Amer. Jl. Ophthal., Vol. XXIII, p. $679,1940$.

2. Julianelle, L. A.-Amer. Jl. Ophthal., Vol. XXIII, p. 633, 1940.

3. Thygeson, P.-Amer. Arch. Ophthal., Vol. XXIX, p. 1000

4. MacCaLian, A. F.-Trans. Ophthal. Soc. U.K., 1942.

5. SorSBY, A.-Brit. Jl. Ophthal., Vol. XXIX, p. 511.

6. Meenan, P. N.-Irish Jl. Med. Sc. Nov.-Dec., 1945. 